\title{
O DESCARTE DE EMBRIÕES EM FACE DOS DIREITOS DA PERSONALIDADE
}

\author{
SARITA VON RÖEDER MICHELS
}




\title{
O DESCARTE DE EMBRIÕES EM FACE DOS DIREITOS DA PERSONALIDADE
}

\author{
Sarita Von Röeder Michels
}

\begin{abstract}
RESUMO
As novas técnicas de reprodução humana levadas a efeito no âmbito da Medicina, especialmente através da fertilização in vitro, exigem posicionamento da comunidade científica em face dos questionamentos delas decorrentes. O tratamento religioso, ético e jurídico dado à reprodução humana convencional não se aplica àquela que a ciência recente coloca à disposição da sociedade. O Direito, a Bioética e o Biodireito, de forma interdisciplinar, buscam o aperfeiçoamento doutrinário e legal a fim de recepcionar as novas descobertas de ciência médica. Assim, o presente estudo pretende, em linhas sinópticas, analisar o descarte de embriões em face das teorias da personalidade.
\end{abstract}

\section{Palavras-chave:}

Embriões. Direito. Teorias da personalidade. Bioética. Biodireito.

\section{RESUMEN:}

Las nuevas técnicas de reproducción humana llevadas a efecto en el ámbito de la Medicina, muy especialmente por la fertilización in vitro, exigen tomada de posición de la comunidad científica frente a los cuestionamientos que de allí surgen. El tratamiento religioso, ético y jurídico dado a la reproducción humana convencional no se aplica aquella que la ciencia dispone a la sociedad moderna. El Derecho, la Bioética y el Bioderecho, de manera interdisciplinaria, buscan el perfeccionamiento doctrinario y legal con el fin de recepcionar las nuevas descubiertas da la ciencia médica. El presente estudio tiene por escopo, en líneas sinópticas, analizar el descarte de embriones frente a las teorías de la personalidad asentadas por la doctrina jurídica tradicional.

\section{Palabras claves:}

Embriones. Derecho. Teorias de la personalidad. Bioética. Bioderecho.

\footnotetext{
'Graduada em Direito pela Universidade Federal do Paraná (1980), especialista em Direito Processual Civil pela Universidade Tiradentes - Sergipe (1996) e doutoranda em Ciências Jurídicas e Sociais pela Universidad del Museo Argentino, coordenadora dos Juizados Especiais e Turmas Recursais do Tribunal de Justiça do Estado do Tocantins, Juíza Titular da Vara do Juizado Cível e Criminal da Comarca de Guarai -TO e professora de nível superior, colaboradora da Faculdade Integrada de Ensino Superior de Colinas do Tocantins.
} 


\section{INTRODUÇÃO}

A evolução da pesquisa científica no campo da medicina tem representado verdadeira angústia para a sociedade. Se por um lado significa a possibilidade de cura de enfermidades devastadoras como o câncer e a aids, por outro também pode ser a realização de todos os temores que a literatura de ficção científica tão bem coloca à disposição do leitor ou do espectador. Nunca, em tempo algum, foi tão presente a luta entre o bem e o mal. Também nunca houve a necessidade de reunir-se tantas áreas do conhecimento para um mesmo fim: delimitar a ação do homem para a preservação de sua própria espécie.

A evolução do conhecimento trouxe para o ser humano uma imensa gama de necessidades que e a ciência, através da chamada pesquisa científica, trata de satisfazer.

Entre as necessidades da vida atual, as da paternidade e maternidade, inicialmente bem individuais, se confundem com uma necessidade inconsciente coletiva de preservação e melhora das condições de vida da própria espécie. Neste contexto encontra-se o Projeto Genoma Humano e a reprodução assistida.

O Projeto Genoma Humano pode ser definido como um empreendimento internacional, iniciado formalmente em 1990, projetado para durar 15 anos e que, congregando cerca de 1000 membros de 50 países, conta com a HUGO - Human Genome Organization para coordenar a colaboração ao projeto.

O consórcio internacional, liderado pelo NHGRI - Instituto Nacional de Pesquisa do Genoma Humano dos Estados Unidos e pelo Instituto Senger no Reino Unido, em 14 de abril de 2003, anunciou oficialmente a conclusão do projeto de decifrar a estrutura do DNA humano. Cumprindo os objetivos iniciais de: a) identificar e fazer o mapeamento dos cerca de 80 mil genes que se calculava existirem no DNA das células do corpo humano; b) determinar as seqüências dos três bilhões de bases químicas que compõem o DNA humano; c) armazenar essa informação em bancos de dados, desenvolver ferramentas eficientes para analisar esses dados e torná-los acessiveis para novas pesquisas biológicas, informaram a conclusão do mapeamento de três bilhões de bases do DNA humano, disponibilizando os dados à comunidade científica e acadêmica. 
Evidentemente que no desenvolver das pesquisas novos conhecimentos foram agregados aos campos da Biologia, da Genética e da Medicina, exigindo um novo tratamento jurídico que direcionasse a atividade de pesquisa e estabelecesse responsabilidades no tocante à aplicação dos resultados das novas descobertas.

Nada pode ser comparado ao salto dado pelo conhecimento a respeito da reprodução humana e, conseqüentemente, vemos o homem voltado para o próprio homem e sua origem.

Foram desenvolvidas novas técnicas de reprodução humana e, com elas, abre-se um imenso leque de possibilidades para pesquisa, o que exige um posicionamento da própria humanidade através da comunidade científica.

Assim é que, enquanto o projeto genoma possibilita a reprodução humana através da fertilização in vitro, surgem novos questionamentos e, apenas um deles, é dizer, na esfera do Direito, se o embrião possui ou não personalidade.

$\mathrm{O}$ tratamento religioso, ético e jurídico dado à reprodução humana convencional não se aplica mais àquela que a ciência recente coloca à disposição da sociedade. Desta realidade surgem novos ramos do conhecimento como a Bioética e o Biodireito que, de forma interdisciplinar, buscam fundamentar o aperfeiçoamento doutrinário e legal que, de forma adequada, recepcione as novas descobertas de ciência médica.

Assim, o presente estudo pretende, em linhas sinópticas, analisar o descarte de embriões em face das teorias da personalidade.

\section{ABIOÉTICA}

A expressão bioética foi utilizada pela primeira vez por Van Rensselaer Potter, em 1970, em um artigo, Bioethics: The Science of Survival, publicado na revista Zygon 5. Em 1971 Potter publicou o livro, Bhioethic: brige to the future. No entanto, o termo ganhou difusão na comunidade científica através dos trabalhos de André Hellegers que, na Universidade de Georgetown, iniciou os estudos 
de Bioética médica. ${ }^{2}$

A palavra bioética, segundo as lições de Jorge Bustamante Alsina, ${ }^{3}$ se compõe de duas raízes gregas que fazem alusão a duas magnitudes de profunda significação: bio "(vida) y ethos " (ética dos valores humanos), sendo definida como "el estudio sistemático de la conducta humana en el área de las ciencias de la vida y el cuidado de la salud, encuanto que dicha conducta es examinada a la luz de los valores y los princípios humanos"

Assim, é possível dizer que a bioética se ocupa das implicações ético-morais resultantes dos avanços tecnológicos nas áreas da Medicina e da Biologia e, sendo ramo transdiciplinar, recebe influência da Sociologia, Biologia, Medicina, Psicologia, Teologia, Direito e mais profundamente da Filosofia.

Segundo o Doutor Volnei Garrafa ${ }^{4}$ a Bioética está para auxiliar na tomada de decisões relativas a problemas permanentes como exclusão social, aborto e racismo, ou aqueles emergentes como a clonagem, os transplantes e as técnicas reprodutivas, ainda que alguns pensem serem estas últimas o seu objeto de estudos.

Assim, de aceitar-se a definição de que o papel da Bioética é o estudo da moralidade da conduta humana na área das ciências da vida ${ }^{5}$ e, portanto, desprovida de qualquer poder coercitivo ou de resolução dos problemas e conflitos gerados pelo avanço das pesquisas e técnicas que afetam a vida do ser humano. Importante é saber que este ramo do conhecimento está mais difundido entre aos pesquisadores das ciências biomédicas e, como tal, vem servindo de fundamento moral e ético no desenvolvimento de pesquisas e novas técnicas.

\footnotetext{
${ }^{2}$ SILVA, Adilson Cunha. Direito, bioética e (bio)tecnociências: a emergência de um novo paradigma científico para as pesquisas jurídicas sobre novas (bio)tecnologias, in Diritto \& Diritti - Rivista giurídica elettronica, publicado na Internet no endereço http://www.diritt.it, ISSN11278579, Abril 2009, p. 22-23, http://www.diritt.it/pdf/27693.pdf.

${ }^{3}$ Las nuevas tecnologias biomédicas frente a La ética y El derecho. In: La Ley, 1996, p. 1017.

"Istoé on line de 10.09.2003.

'RUSS, Jacqueline. Pensamento ético contemporâneo. São Paulo: 1999, p. 138.
} 


\section{BIODIREITO}

A renovação causada nas ciências biomédicas, com o surgimento da Bioética e toda a sua gama de questionamentos, provocou o início de discussões no campo do Direito, especialmente a partir da constatação de que existe um descompasso entre a normatização da conduta humana e a utilização dos novos conhecimentos biomédicos. A atividade científica não está alijada do contexto ideológico em que se realiza e o cientista não se afasta de seus próprios valores e de seus referenciais ideológicos no ato da produção científica. Assim, a pura restrição ética não basta para impedir a liberdade absoluta na produção de conhecimentos que envolvem a vida e a sobrevivência do homem neste planeta. Ao contrário, esta liberdade subordina-se a interesses que transcendem a própria ciência. ${ }^{6}$ Neste caso a regulamentação da conduta através do Direito se faz extremamente necessária, posto que é ciência do dever ser que delimita os caminhos da sociedade em que viverá o indivíduo.

Ainda não é absoluto o entendimento de que o Biodireito seja uma nova ramificação dentro do próprio Direito. Se considerado o termo, teríamos uma definição como o direito da vida. Neste sentido não haveria razão de existir um biodireito, porquanto a proteção e garantia à vida encontra-se em todos os ramos do Direito. No entanto, a extrema especialização de algumas áreas do conhecimento, a exemplo da biotecnologia, técnicas de manipulação da vida no planeta, têm reclamado estudo específico e não menos especializado por parte dos juristas. Assim, considerando que é da ciência jurídica que emanam as normas traduzidas nas leis que regulam o comportamento em sociedade, a evolução do Biodireito passa, inclusive, pelo aperfeiçoamento de institutos já existentes e, talvez, pelo surgimento de novos, porquanto a visão do homem quanto a si mesmo é que determinará a sociedade do futuro.

Ainda que muitos discordem, certo é que os tradicionais conceitos jurídicos necessitam atualização. Enquanto o Biodireito não oferece novas respostas porque ainda se encontra em

${ }^{6}$ JAPIASSU, Hilton. O mito da neutralidade científica. Rio de Janeiro: Imago, 1975, p. 183- 
construção, aquela a respeito da personalidade do embrião há de ser buscada entre as várias teorias jurídicas existentes e assentes no Direito.

\section{OS DIREITOS PERSONALÍSSIMOS}

A personalidade é um atributo jurídico institucionalizado e correspondente a um conjunto de regras declaratórias das condições e dos limites da atividade das pessoas.

O Direito conhece, define e ampara duas categorias de pessoas: o indivíduo, o ser humano, a pessoa natural, a pessoa física e mais, grupos de indivíduos constituídos na forma da lei a que o direito, por ficção jurídica, atribui personalidade própria e denomina pessoas jurídicas.

No presente estudo, voltado a perquirir sobre a personalidade do embrião, interessa analisar as questões que envolvem apenas a pessoa natural, a pessoa física, o ser humano, o indivíduo, porquanto a idéia de personalidade está intimamente ligada à pessoa.

A palavra pessoa evoluiu do latim persona que, nada mais era do que um tipo de máscara utilizada no teatro romano. Os atores romanos adaptavam a máscara ao rosto de tal forma que suas vozes ecoavam. Assim, personare significava ressoar, ecoar. O sentido da palavra foi evoluindo e, mais tarde, passou a significar o papel de cada ator, aquilo que ele externamente representava no contexto da peça teatral. No desenvolver do conhecimento e com a estruturação do Direito, a palavra passou a significar a atuação de cada indivíduo no mundo jurídico e, finalmente, até os dias atuais, representa o próprio indivíduo, a pessoa, sujeito de direitos e obrigações.

Independente de outras conhecidas construções jurídicas, a existência do Direito se justifica apenas em razão da vida do ser humano, da pessoa física, porquanto regula a vida deste, suas interrelações e as relações deste com o ambiente, natural ou social, em que vive. "O Direito é realidade universal. Onde que exista o homem aí existe o direito como expressão de vida e de convivência""

Assim é que toda pessoa é sujeito de direito, ou seja, é aquela a

'REALE, Miguel. Filosofia do direito. 17.Ed., São Paulo: Saraiva, 1996, p. 9. 
quem a lei atribui direitos e obrigações. Excetuando-se as pessoas jurídicas, somente as pessoas físicas, os seres humanos, podem ser sujeito de direito.

De uma forma geral, todo o sistema jurídico moderno reconhece a pessoa humana como valor supremo do Direito. As constituições e o ordenamento legal definem em crescente abrangência os direitos básicos da pessoa humana. Após longa tradição de solenes Documentos nacionais e internacionais ${ }^{8}$ estes direitos foram sendo reafirmados em outros instrumentos de caráter internacional, , sendo presente na atualidade o "reconhecimento da dignidade inerente a todos os membros da familia humana e seus direitos gerais e inalienáveis constitui o fundamento da liberdade, dajustiça e da paz no mundo."

Todos os doutrinadores reconhecem que estes direitos não correspondem a um número fixo, porquanto as transformações por que passa a sociedade, especialmente em face da globalização e dos avanços tecnológicos, fazem com que surja uma nova realidade e, com ela, novas situações que repercutem sobre as pessoas e suas relações. Mas, conforme ensina o ilustre Professor Doutor Marcelo Urbano Salerno, ${ }^{10}$ estes direitos poderiam ser agrupados em classes como: direito à vida, direito à liberdade, direito à honra, direito à integridade física e direito à privacidade.

De todos os direitos, naturalmente, o direito à vida é o primeiro, o principal. Pois bem, decorrente dele, cabe ao Direito Civil tratar do início e fim da personalidade. Para tanto, em caráter doutrinário, foram desenvolvidas teorias que tratam, cada uma, de justificar a seu modo o início da personalidade.

\section{AS TEORIAS DA PERSONALIDADE}

"Personalidade, na terminologia jurídica, é a aptidão para ser

\footnotetext{
${ }^{8}$ Magna Carta (1215); Bil of Rights (1699); a Declaração de Independência dos Estados Unidos (1776); a Declaração dos Direitos do Homem e do Cidadão (1789) e a Declaração Universal dos Direitos Humanos (1948) ONU.

'Declaração Americana dos Direitos e Deveres do Homem; Convenção Americana sobre Direitos Humanos. Pacto de San José da Costa Rica; Declaração Universal sobre o Genoma Humano e dos Direitos Humanos.

${ }^{10}$ Derecho civil profundizado. Buenos Aires: Ciedad Argentina, 1998, p. 247-275.
} 
sujeito ou titular de direito" $" 11$ e, como atributo da pessoa humana, sua duração é a vida. Desde que vive e enquanto vive, o homem é dotado de personalidade. A personalidade em si não é um direito, "mas é fonte e pressuposto de todos os direitos subjetivos", , e estabelecer em que momento tem início a personalidade civil é problema que envolve antiga controvérsia.

Independente da citação nominal e expressa dos termos legais, a quase totalidade da legislação vigente declara que " a personalidade civil do homem começa do nascimento com vida", embora também ofereçam proteção os direitos do nascituro, atribuindo a este o direito de nascer.

O posicionamento doutrinário atual remonta ao Direito Romano, conforme ensinam Eduardo Espínola ${ }^{13}$ e Santos Sifuentes. ${ }^{14}$ Da leitura de textos legais da época percebe-se que não havia entendimento preciso a respeito da questão, porquanto ao tempo de Justiniano foi cunhada a regra onde considera-se o nascituro já nascido quando se trata de proteger seus interesses. ${ }^{15}$ No entanto, para Papiano "disse que o homem ainda não existe antes do parto ${ }^{16}$ para Ulpiano "o parto, antes que seja dado à luz, é porção da mulher ou de suas entranhas" " e para Juliano "aqueles que estão no útero, quase em todo direito civil entende-se estar existentes na natureza ${ }^{18}{ }^{\mathrm{o}}$ que leva Windscheid a concluir que na doutrina romana "o feto no útero materno ainda não é homem, porém, se nasce capaz de direito, a sua existência se computa desde a época da concepção." ${ }^{19}$ Certo é que, além de outros requisitos, a doutrina romana ainda exigia que o nascido tivesse forma humana para que se lhe atribuísse personalidade, o que ainda perdura em algumas legislações, a exemplo do Código Civil de Espanha. ${ }^{20}$

Decorrente da doutrina romana, para determinar o início da

\footnotetext{
"MONTORO, André Franco. Introdução à ciência do direito. São Paulo: RT, 1994, p. 495.

${ }^{12}$ RUGGIERO, Roberto de. Instituições de direito civil. Campinas/SP: Bookseller, 1999. p. 142.

${ }^{13}$ in Sistema do direito civil brasileiro. Rio de Janeiro: Editora Rio, 1977. p. 341-346.

${ }^{14}$ in Derechos personalisimos. Buenos Aires: Editorial Astrea, 1995. 234-235.

1 s"infans conceptus pro jan nato habetur quotis de commodis agitur"

16، "partus nondum editus homo non recte fuisse dicitur" (D. 35, Fr, 9, par 1)

17 "partum antequam edatur mulieris portio est, vel viscerum" (D. 25, 4, Fr. 1, par 1).

18."qui in uterosunt in Toto pene jure civile intelliguntur in rerum natura esse"

${ }^{19} \mathrm{BEVILACQUA,} \mathrm{Clóvis.} \mathrm{Teoria} \mathrm{geral} \mathrm{do} \mathrm{direito} \mathrm{civil.} \mathrm{Rio} \mathrm{de} \mathrm{Janeiro:} \mathrm{Editora} \mathrm{Rio,} \mathrm{1980.} \mathrm{p.} 77$.

${ }^{20, “}$ Artículo 30. Para los efectos civiles, sólo reputará nacido el feto que tuviere figura humana y viviere venticuatri horas enteramente desprendido del seno materno".
} 
personalidade, estabeleceram-se as teorias natalista, concepcionista e concepcionista condicionada.

Segundo a teoria natalista, a personalidade é adquirida a partir do nascimento com vida, porquanto propugna que antes disto o nascituro teria mera expectativa de direitos. Condiciona a existência do ser humano ao nascimento, entendendo que a vida autônoma se dá em razão do processo respiratório. Assim a demonstração de que o neo nato respirou tem servido de fundamento básico para concluir que há vida extra-uterina autônoma. A prova da respiração se faz através de um conjunto de técnicas denominadas docimasias respiratórias-diretas, as quais comportam diferentes análises. ${ }^{21}$

Adotam esta teoria a legislação brasileira ${ }^{22}$ e grande parte da legislação de outros paises a exemplo de Portugal, Suíça, Itália e Alemanha, ${ }^{23}$ contando a corrente com ilustres doutrinadores brasileiros. $^{24}$

Para a teoria concepcionista, conforme indica a própria denominação, a personalidade tem início com a concepção. Neste caso, a concepção é entendida como a fecundação decorrente do encontro entre os genes paterno e materno, com a conseqüente nidação, ou seja a fixação do ovo ao útero materno. Neste caso, pouco importam as condições da fecundação, se de liberta vontade ou fruto de violência, o ser humano em gestação deverá vir à luz, porquanto tem direito natural de sobreviver à gestação. Esta teoria encontra-se recepcionada por um número reduzido de países, valendo mencionar aqui Argentina e Áustria, porém conta com o apoio de juristas de renome como Teixeira de Freitas, André Franco Montoro, Limongi França e outros.

A teoria concepcionista condicionada une as duas teorias anteriores para justificar que, existindo os direitos da personalidade em forma latente, não basta o nascimento com vida e sim que ela

\footnotetext{
${ }^{21}$ GOMES, Hélio. Medicina legal. São Paulo: Freitas Bastos, 1957. p. 570-574.

${ }^{22}$ “Art $2^{\circ}$. A personalidade civil da pessoa começa do nascimento com vida, mas a lei põe a salvo, desde a concepção, os direitos do nascituro. Lei n ${ }^{\circ} 10.406$, de 10.01.2002, Código Civil.

${ }^{23}$ MOREIRA, Márcio Martins. A teoria personalíssima do nascituro. São Paulo: Livraria Paulista, 2003. p. 31-35. Eduardo Espínola, Sílvio Rodrigues, Washington de Barros Monteiro, Orlando Gomes.

${ }^{24}$ Eduardo Espindola; Sílvio Rodrigues, Washington de Barros Monteiro, Orlando Gomes.
} 
efetivamente se estabeleça. Neste caso, ao nascer o concepto com vida, seus direitos remontam à concepção. Esta teoria é recepcionada pelo direito civil francês e holandês. ${ }^{25}$

Da análise das três teorias constata-se que todas têm o início da vida por marco referencial à aquisição da personalidade. Seja o início através da concepção ou do nascimento com vida, diferem apenas no momento em que o fato ocorre.

Estabelecer o início da vida não é tarefa para o Direito. Para isto ele há de informar-se em outros ramos do conhecimento e, assim, antes de prosseguir, mister se faz recorrer à Biologia para a determinação do início da vida.

\section{O INÍCIO DA VIDA}

A reprodução humana é fenômeno individual, porquanto a vida humana, o fenômeno vital, é permanente e contínuo. A vida de uma nova pessoa é que tem início e, para atender ao início do indivíduo, da pessoa, é que foram desenvolvidas as teorias da personalidade. Para determinar este início de vida é necessário sejam estabelecidos critérios a fim de que o Direito, fundado em bases sólidas e o mais próximo possível da realidade, estabeleça a partir de quando o bem jurídico deva ser tutelado.

Em face da fertilização in vitro e das téenicas de congelamento de embriões humanos foi levantada a questão relativa ao exato momento em que se deva considerar juridicamente o nascituro e, para tanto, importam alguns esclarecimentos.

O quadro a seguir é apresentado pelo Professor Doutor José Roberto Goldim, ${ }^{26}$ onde demonstra alguns critérios utilizados para fixar o início da vida de uma pessoa. Interessante observar que até o sexto ou sétimo dia ainda não ocorreu a chamada nidação, que o autor denomina de implantação uterina. Este fato, até poucos anos, era desconhecido da comunidade acadêmica e hoje exige sejam repensados não só os conceitos existentes a respeito do início da vida

\footnotetext{
${ }^{25}$ DINIZ, Maria Helena. Teoria geral do direito civil. São Paulo: Saraiva, 2000. p. 121.

${ }^{26}$ Início da vida de uma pessoa humana. Núcleo interdisciplinar de Bioética da Universidade Federal do Rio Grande do Sul, www.ufrgs.br
} 
humana, mas também a denominação a eles atribuída.

\begin{tabular}{|c|c|c|}
\hline Tempo decorrido & Característica & Critério \\
\hline $0 \mathrm{~min}$ & Fecundação fusão de gametas & Celular \\
\hline 12 a 24 horas & Fecundação - fusão dos pró-núcleos & Genotípico estrutural \\
\hline 2 dias & Primeira divisão celular & Divisional \\
\hline 3 a 6 dias & Expressão do novo genótipo & Genotípico funcional \\
\hline 6 a 7 dias & Implantação uterina & Suporte materno \\
\hline 14 dias & Células do individuo diferenciadas $\mathrm{d}$ anexos & Individualização \\
\hline 20 dias & Notocorda maciça & Neural \\
\hline 3 a 4 semanas & Início dos batimentos cardíacos & Cardiaco \\
\hline 6 semanas & A aparência humana e rudimento de todos os órgãos & Fenotípico \\
\hline 7 semanas & Respostas reflexas à dor e à pressão & Senciência \\
\hline 8 semanas & $\begin{array}{l}\text { Registro de ondas eletroencefalográficas (tronco } \\
\text { cerebral) }\end{array}$ & Encefálico \\
\hline 10 semanas & Movimentos espontâneos & Atividade \\
\hline 12 semanas & Estrutura cerebral completa & Neocortical \\
\hline 12 a 16 semanas & Movimentos do feto percebidos pela mãe & Animação \\
\hline 20 semanas & Probabilidade de $10 \%$ para sobrevida fora do útero & $\begin{array}{l}\text { Viabilidade extra- } \\
\text { uterina }\end{array}$ \\
\hline 24 a 28 semanas & Viabilidade pulmonar & Respiratório \\
\hline 28 semanas & Padrão sono-vigília & Autoconsciência \\
\hline 28 a 30 semanas & Reabertura dos olhos & Perceptivo-visual \\
\hline 40 semanas & Gestação a termo ou parto em outro período & Nascimento \\
\hline $\begin{array}{l}2 \text { anos após o } \\
\text { nascimento }\end{array}$ & "Ser moral" - Michel Tooley & $\begin{array}{l}\text { Linguagem para } \\
\text { comunicar vontades. }\end{array}$ \\
\hline
\end{tabular}

Dispensado por hora o embasamento filosófico e religioso, a propedêutica da medicina fetal exposta no Tratado de Obstetrícia da Federação Brasileira das Sociedades de Ginecologia e Obstetrícia, ${ }^{27}$ descreve as fases evolutivas do concepto e, para o presente estudo, importam as informações ali encontradas.

A fecundação ocorre no momento em que o espermatozóide penetra o óvulo e o resultado "éo encontro do pró-núcleo masculino com o feminino, com a organização dos constituintes do futuro núcleo celular, originando o ovo."

A divisão do ovo resulta na etapa bicelulada que é o início do desenvolvimento embrionário do concepto. "Essas duas primeiras células, conhecidas como blastômeros, iniciam um processo de clivagem ou segmentação até a formação da mórula" e então, a fase de blastócisto é alcançada tão logo entre o ovo no útero, permanecendo livre na cavidade por um período de três a cinco dias.

\footnotetext{
${ }^{27}$ Rio de Janeiro: Livraria e Editora Revinter Ltda., 2000. p. 659.
} 
A nidação ocorre, no sétimo ou oitavo dia, quando o blastócisto entra em contato com o endométrio uterino e sua camada externa, trofoblasto, se fixa na parede uterina para continuar seu crescimento.

A fase embrionária ocorre na terceira semana, ou décimo quarto dia, terminando ao final da oitava semana. Neste período ocorre a formação dos principais sistemas orgânicos fetais, partindo das três camadas germinativas.

Bem, em linhas reduzidas é este o início da vida demonstrado pela Biologia Humana.

\section{CONCLUSÕES}

Todo o tratamento jurídico, doutrinário ou legal existente se refere ao nascituro, aquele que está por nascer, tendo em conta a condição de estar sendo gerado no ventre de uma mulher.

Mais ainda, como não poderia deixar de ser, todas as teorias entendem a concepção como fato ocorrido dentro do corpo da mulher, porquanto a época em que foram elaboradas nem se imaginava possibilidade de fecundação in vitro.

Ainda que muito se diga da impropriedade deste tratamento doutrinário nos dias atuais, isto efetivamente não se apresenta como uma realidade fática. Hoje o que se possibilita é uma melhor compreensão do processo que gera a vida e, com isto, também uma melhor definição de seus estágios. A fecundação já não corresponde mais à concepção. São fatos diferentes e assim deverão ser tratados pelo Direito.

Os embriōes conservados por criogenia não podem ser considerados pessoas pelo simples fato de que não foram ainda concebidos como seres humanos, porquanto esta condição só se afirmará quando da respectiva implantação uterina e correspondente nidação, dando início à gravidez. Antes disto existirá, até que seja possível a gestação sem o concurso de uma mulher, apenas uma verdadeira expectativa de vida humana e, esta, não resta dúvida, é "um processo que começa com a gestação, na qual uma realidade biológica vai tomando, corpórea e sensitivamente, configuração
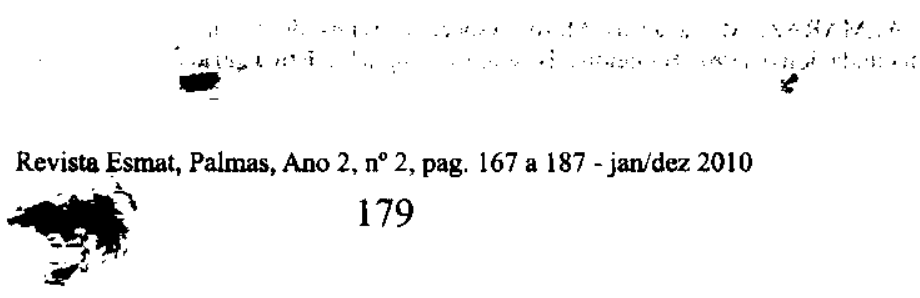
humana." 28

Após a nidação, iniciada a gestação, aplicam-se as teorias da personalidade, porquanto se trata da defesa do mesmo direito de viver que fundamenta a penalização do aborto.

Atualmente os estudiosos da genética humana têm utilizado a denominação de pré-embrião para designar o estágio da divisão celular in vitro, antes de ser implantado nas entranhas femininas, entendendo que, nesta fase, não podem ser considerados seres humanos, conforme exposto pelo ilustre relator do Parecer 23/96 do Conselho Federal de Medicina que se anexa ao presente.

Assim, o descarte de embriões através da interrupção do processo de preservação por criogenia não pode ser considerado ato anti-ético ou vir a ser considerado como ilícito. Estando o préembrião desprovido de qualquer personalidade, seu descarte não pode ser comparado ao aborto.

Este conjunto de células pode efetivamente representar um futuro ser humano e, como tal, deve estar protegido pela lei em razão de representar parte do patrimônio genético da humanidade porém, atribuir-lhe personalidade contraria todos os fundamentos teóricos justificadores desta.

A evolução do Direito experimentou inúmeras modificações do statusquo.

O conhecimento das bases químicas que compõem o DNA humano e o desenvolvimento das novas técnicas de reprodução humana reclamam, mais uma vez, a reformulação dos conceitos jurídico-doutrinários que informaram a atividade humana até os dias atuais.

Apenas por entender que do debate e da confrontação de idéias é que surgem soluções, vale perquirir qual valor teria o Direito em face de um ser humano desprovido de cérebro.

\section{REFERENCIAS}

BARROS MONTEIRO, Washington de. Curso de Direito Civil. v. 1. São Paulo: Saraiva, 1989.

\footnotetext{
${ }^{21}$ ALMARAZ, Maria Jesús Moro. Aspectos civiles de La inseminación artificial y de La fecundación in vitro. Barcelona: Bosch, 1998, apud in Ética geral e profissional. p. 140.
} 
BEVILAQUA, Clóvis. Teoria Geral do Direito Civil. Rio de Janeiro: Editora Rio, 1980.

DINIZ, Maria Helena. Teoria Geral do Direito Civil. São Paulo: Saraiva, 2000.

ESPÍNOLA, Eduardo. Sistema do Direito Civil Brasileiro. Rio de Janeiro: Editora Rio, 1977.

GOMES, Hélio. Medicina Legal. São Paulo: Freitas Bastos, 1957.

GOMES, Orlando. Introdução ao Direito Civil. Rio de Janeiro: Forense, 1995.

MONTORO, André Franco. Introdução à Ciência do Direito. São Paulo: RT, 1994.

MOREIRA, Marcio Martins. A teoria personalíssima do nascituro. São Paulo: Livraria Paulista, 2003.

NATALINI, José Renato. Ética geral e profissional. São Paulo: RT, 2001.

PESSINI, Léo \& BARCHIFONTAINE, Christian de Paul de. Problemas atuais de bioética. $4^{\mathrm{a}}$ ed. São Paulo, 1997.

REALE, Miguel. Filosofia do Direito. $17^{\mathrm{a}}$ ed., São Paulo: Saraiva, 1996.

Revista Istoé on line de 10.09.2003.

RODRIGUES, Silvio. Direito Civil, Parte Geral. São Paulo: Saraiva, 1995.

RUGGIERO, Roberto de. Instituições de Direito Civil. Campinas/SP: Bookseller,1999. 
RODRIGUES, Silvio. Direito Civil, Parte Geral, v.1. São Paulo: Saraiva, 1997.

RUSS, Jacqueline. Pensamento ético contemporâneo. São Paulo: 1999.

SALERNO, Marcelo M. Derecho Civil profundizado. Buenos Aires: Ciudad Argentina, 1998.

SILVA, Adilson Cunha. "Direito, Bioética e (Bio)Tecnociências: a emergência de um novo paradigma científico para as pesquisas juridicas sobre novas (bio)tecnologias ", In: Diritto \& Diritti Rivista giuridica elettronica, publicado na Internet no endereço http://www.diritto.it, ISSN 1127-8579, Abril 2009, p. 22-23, http://www.diritto.it/pdf/27683.pdf.

PEREIRA, Caio Mario da Silva. Instituições de Direito Civil. v. 1. Rio de Janeiro: Forense, 1995.

TEPEDINO, Gustavo. Temas de Direito Civil. Rio de Janeiro: Renovar, 1999.

Núcleo Interdisciplinar de Bioética da Universidade Federal do Rio Grande do Sul, www.ufrgs.br

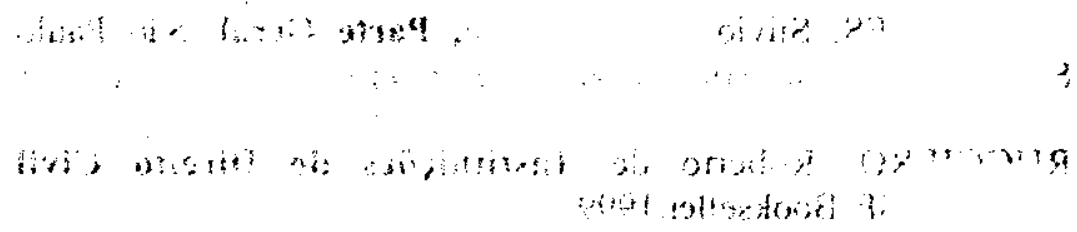




\section{ANEXO}

PARECER CFM No 23/96, aprovado em 11/09/96. A Resolução $n^{\circ} 1358 / 92$, que adota as normas éticas para utilização das técnicas de reprodução assistida, proíbe o descarte ou destruição de pré-embriões criopreservados. Porém, necessário se faz que o CFM promova estudos com o objetivo de aprofundar-se sobre a necessidade de atualização das referidas normas sobre este e outros questionamentos a respeito.

Relator: Antônio Henrique Pedrosa Neto

Consulta:

A presente consulta, originária do Conselho Regional de Medicina do Estado de São Paulo, foi motivada pela Unidade de Reprodução Humana - HIAE, do Hospital Israelita Albert Einstein, que solicitou manifestação daquele Regional sobre o descongelamento de embriões e sua conseqüente inutilização.

Eis a integra da consulta:

"A UNIDADE DE REPRODUÇÃO HUMANA-HIAE, iniciou seus trabalhos em setembro de 1990 , desde o início realizando a crio-preservação de embriões.

A relação entre o casal e a URH estava estabelecida no contrato anexo, onde previa-se o descongelamento dos embriões, e a sua conseqüente inutilização quando o casal se manifestasse.

Entretanto, após a resolução 1358/92, do Conselho Federal de Medicina - CFM, ficou proibida a inutilização destes embriões. No momento, vários casais manifestaram seu desinteresse pela preservação dos embriões congelados.

Desta maneira, solicitamos a este Conselho que se manifeste sobre o que fazer com estes embriões? - No momento da assinatura do contrato, a opção pela destruição do embrião era viável, pois não existia recomendações contrárias.

No aguardo de seu breve pronunciamento, subscrevemo-nos.

Atenciosamente,

Dr. Sidney Glina - Coordenador da Equipe URH

Em anexo à consulta vinham vários termos de autorização de descongelamento e descarte de embriões de casais que participaram de procedimentos de fertilização assistida (FIV, PROST, ZIFT e 
GIFT) na referida Unidade de Reprodução Humana, bem como cópia de informe consentido para congelamento e preservação de pré-zigotos, onde se esclarecia a técnica de fertilização "in vitro" e o conseqüente congelamento dos pré-zigotos que excedam o número de quatro, que serão transferidos "a fresco".

O informe explica, ainda, que a criopreservação procura beneficiar os participantes dos programas de fertilização assistida, reduzindo os riscos de gestações múltiplas e suas complicações obstétricas, ao mesmo tempo que cria a oportunidade de novas transferências para a obtenção de gravidez com a transferência de embriões desenvolvidos a partir de pré-zigotos criopreservados. Tece comentários detalhados sobre a criopreservação e informa que os pré-zigotos serão guardados enquanto participarem do programa de FIV. Frisa, porém, que em qualquer caso os mesmos serão descongelados e descartados após decorridos três anos.

Por fim, informa que o HIAE cobrará uma taxa trimestral de manutenção dos pré-zigotos criopreservados.

\section{Parecer}

Através da Resolução CFM n ${ }^{\circ} 1358 / 92$, de 11 de novembro de 1992, o Conselho Federal de Medicina normatizou as técnicas de Reprodução Assistida, preenchendo um vazio na legislação, haja vista que a medicina brasileira já dominava a técnica, há alguns anos, através de centros de reprodução assistida instalados em vários estados do País.

Para tanto, o Conselho Federal de Medicina convidou a Federação Brasileira das Sociedades de Ginecologia e Obstetrícia FEBRASGO, a Sociedade Brasileira de Reprodução Humana, a Sociedade Brasileira de Genética Clínica e a Sociedade Brasileira de Pediatria, além de especialistas renomados nacionalmente sobre o assunto, para conjuntamente proceder a revisão bibliográfica nacional e internacional e oferecer ao plenário do CFM, para discussão e aprovação, um conjunto de normas que disciplinasse o uso da técnica no país, dentro de padrões internacionais. A comissão lastreou o seu trabalho com a preocupação do rigor técnico e ético, procurando adequar-se às normas legais existentes, sem, no entanto, impor barreiras ao seu desenvolvimento, buscando o melhor da experiência internacional no desenvolvimento das várias técnicas de Reprodução Assistida. 
Visando sempre o bem-estar do homem e a sua satisfação biopsicossocial, e com a convicção de que os avanços da ciência e da medicina devem estar sempre voltados para esse objetivo, o CFM regulamentou um procedimento médico que envolve aspectos de natureza científica, ética, legal e filosófica, tocando em um assunto, até então, privativo do Criador.

Portanto, esse conjunto de normas, fruto de amadurecido debate e profunda reflexão, visou permitir o desenvolvimento médicocientífico sem infringir às normas legais ou violentar os códigos sociais. Dentro desse espírito, o capítulo V - criopreservação de gametas ou pré-embriões das normas adotadas pela Resolução CFM 1358/92, expressa:

"2- O número total de pré-embriões produzidos em laboratórios será comunicado aos pacientes, para que decidam quantos préembriões serão transferidos "a fresco", devendo o excedente ser criopreservado, não podendo ser descartado ou destruído."

Desta forma, os Centros de Reprodução Assistida no pais estão subordinados à Resolução CFM n ${ }^{\circ} 1358 / 92$, que permite a criopreservação de pré-embriões, porém impede o seu descarte ou destruição. Mesmo reconhecendo os custos financeiros que a sua conservação por tempo indeterminado exige, não há no momento outra alternativa a não ser o seu cumprimento.

Os princípios éticos que norteiam a medicina devem estar sempre acima de qualquer interesse que não seja o bem-estar do homem e o desenvolvimento científico contido em limites rígidos estabelecidos pela sociedade, que é sua única beneficiária. Do contrário, a ditadura da ciência e o autoritarismo do conhecimento conduziriam os destinos da humanidade sem conhecer as fronteiras, tornando-se senhora e senhor absolutos da verdade. $\mathrm{O}$ "clic" que permitirá o avanço dos limites que a ciência e a medicina podem ultrapassar terá que ser sempre determinado pelas transformações do pensamento social, e após a certeza do seu significado para o bem do homem e da humanidade.

A Resolução CFM n ${ }^{\circ}$ 1358/92 tem apenas quatro anos de existência e constituiu-se em importante instrumento para o desenvolvimento da técnica em nosso país, colocando-o em situação de igualdade com os países que possuem as legislações mais modernas sobre o assunto. Como exemplo, só recentemente a 
Inglaterra, pioneira da fertilização "in vitro" de gametas humanos, permitiu o descongelamento e descarte de pré-embriões criopreservados.

No entanto, necessário se faz realizar algumas considerações sobre a técnica de Reprodução Assistida através da fertilização "in vitro" com transferência de embriões, permitida e regulamentada por este CFM, particularmente no que diz respeito aos pré-embriões criopreservados. Após estimulação química da ovulação são colhidos um número indeterminado de óvulos que, em contato com os espermatozóides, são fertilizados e desenvolvem-se "in vitro" até alcançar o estágio de 8 células, momento em que são selecionados os pré-embiões a serem transferidos para a cavidade uterina. Os restantes são, então, criopreservados.

A Resolução CFM n ${ }^{\circ}$ 1358/92 limitou a transferência de quatro pré-embriões visando impedir que os Centros de Reprodução Assistida, na busca de melhores resultados, transferissem um número maior de pré-embriões, aumentando os riscos já existentes de gravidez múltipla, com sérios agravos para os fetos e a mãe. Da mesma forma, permitiu a criopreservação, possibilitando, em caso de insucesso ou desejo de nova gravidez, novas tentativas de transferência sem necessidade de novos procedimentos de indução ovulatória, coleta de óvulos e nova fertilização "in vitro".

Caso não fosse permitida a criopreservação, e como não se pode determinar laboratorialmente o número exato de óvulos a serem fecundados e levando-se em conta que a Resolução $n^{\circ}$ 1358/92 limita a transferência de quatro pré-embriões, os excedentes seriam necessariamente descartados. Sabemos que após a transferência dos pré-embriões, a probabilidade de gravidez situa-se, em média, em torno de $20 \%$, variável em função da idade da receptora, o que significa a "rejeição" natural dos pré-embriões transferidos. Por outro lado, nos resultados positivos desenvolvem-se, em média, dois embriões, com o descarte natural dos restantes. Também é fato sabido que após o processo de descongelamento, um número variável de pré-embriões não continuam o seu desenvolvimento, permitindo a sua transferência, o que significa o descarte de préembriões independente de vontade. Ressalte-se, ainda, que durante a fecundação natural através do ato sexual muitos pré-embriões não conseguem o seu desenvolvimento no leito materno, sendo 
descartados por determinação da mãe natureza.

A técnica de fertilização "in vitro", portanto, independente da nossa vontade, determina o descarte de pré-embriões. E como não poderia ser diferente, a técnica imita e ajuda a natureza para que o homem consiga realizar o seu desejo e cumprir o determinismo biológico da reprodução.

Finalmente, entendo que um pré-embrião em estágio de oito células sem desenvolvimento da placa neural não pode ser considerado um ser humano. É uma expectativa potencial de vida. Assim como, também, são expectativas de vida os gametas masculinos e femininos, isoladamente. São partes que se completam para permitir, através de sua fusão, a mágica maior da vida: o ser humano.

Com todo o cuidado que o assunto exige, temos a considerar que em algum momento este Conselho Federal terá que pronunciar-se a respeito da "guarda"por tempo indeterminado dos pré-embriões criopreservados. O acesso cada vez maior da população aos procedimentos de Reprodução Assistida irá exigir em momento muito próximo, uma tomada de posição a esse respeito sob pena de colocar em risco, por questões puramente econômicas, os benefícios que este avanço da medicina colocou à disposição do ser humano, restringindo, cada vez mais, o seu acesso apenas às camadas da população melhor colocadas na escala social.

Portanto, como este e outros questionamentos a respeito das técnicas de Reprodução Assistida têm chegado a este Conselho e por entender que é através da regulamentação que se evitam os desvios e a prática do fato consumado, muitas vezes ferindo princípios éticos e à margem dos dispositivos legais, sugiro a reativação da comissão que elaborou as normas adotadas pela Resolução CFM n ${ }^{\circ} 1358 / 92$, com o objetivo de aprofundar estudos sobre a necessidade de atualização das referidas normas. 